\title{
Aplicação de uma ferramenta musicológica em documentos musicais de um acervo bicentenário
}

\author{
ANTONIO TENÓRIO FILHO \\ Universidade Federal de São João del-Rei (atsf.tenorio@yahoo.com.br)
}

MODESTO FLÁVIO CHAGAS FONSECA

Universidade Federal de São João del-Rei

\section{Introdução}

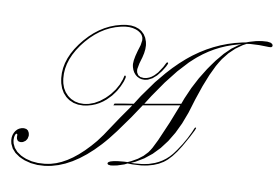

través de características comuns, a historiografia está diretamente conectada à memória, ainda que haja especificidades de ambas, oral e gráfica, quando da narrativa do passado. 0 historiador português Fernando Catroga (1945-) afirma que a "historiografia nasceu como uma nova ars memoriae, crescentemente tornada necessária pela decadência da transmissão oral e pelo alargamento da afirmação da racionalidade" (CATROGA, 2015, p. 56). A oralidade, enquanto primeiro mecanismo de transmissão da música, não deixou de ser praticada com o desenvolvimento da escrita musical. Ainda hoje os dois sistemas coexistem de forma concomitante em algumas sociedades e exclusivo em outras, a oralidade com mais constância em gêneros populares, como na música folclórica, étnica e urbana popular, e a escrita, por sua vez, na música de concerto. A música para o ritual católico encontrou no sistema gráfico estratégia para uma ampla transmissão e método para consolidar a unidade doutrinária. A título de exemplo cabe citar os esforços da Igreja de Roma na Idade Média no esforço para unificar os cânticos para a liturgia, já amplamente disseminados, mas repletos de variantes (CROCKER, 1986, p. 2).

$\mathrm{Na}$ atualidade cânticos transmitidos oralmente são praticados no interior de Minas Gerais, na cidade de São João del-Rei e região, dentro de cerimônias assistidas com a execução de música em sistema gráfico na maior parte do tempo. Em cerimônias paralitúrgicas, tais como tríduos, quinquenas, setenários, novenas e trezenas, há nas novenas sanjoanenses a prática de iniciar com cânticos evocativos e responsoriais em vernáculo, ou seja, em português conforme o quadro abaixo (PIEDOSAS, 1997, p. 212), e transmitidos entre os músicos de forma oral e não escrita. 
Invocações praticadas no início da Novena a Nossa Senhora do Carmo em São João del-Rei

Chegando ao altar, após a devida reverência, todos se ajoelham e a Orquestra (0) inicia o canto que é repetido pelos fiéis (T).

O. Deus vos salve, filha de Deus Pai

T. Deus vos salve, filha de Deus Pai

O. Deus vos salve, Mãe de Deus Filho

T. Deus vos salve, Mãe de Deus Filho

O. Deus vos salve, esposa do Espírito Santo

T. Deus vos salve, esposa do Espírito Santo

O. Deus vos salve, Templo e Sacrário da Santíssima Trindade

T. Deus vos salve, Templo e Sacrário da Santíssima Trindade

Quadro 1: Invocações em novenas em São João del-Rei.

Neste momento a orquestra e coral estão posicionados no coro da igreja, enquanto os celebrantes e fiéis se encontram no plano principal do templo, na Capela Mor e Nave respectivamente. Em resposta à orquestra e coral, celebrantes e fiéis respondem cantando a capella, ou seja, sem acompanhamento instrumental. 0 texto das invocações sanjoanenses é sempre o mesmo nas novenas onde são praticadas. Na região esta prática é observada em diferentes municípios próximos a São João del-Rei, ainda nos limites da região do Campo das Vertentes, a exemplo de Tiradentes e Nazareno, onde são perceptíveis variantes nos cânticos de evocação em novenas em relação àquele praticado em São João del-Rei.

O Brasil possui valioso e expressivo patrimônio arquivístico musical, especialmente em Minas Gerais no que se refere a documentos dos séculos XVIII e XIX. Na medida em que os arquivos de corporações musicais, orquestras, corais e instituições de preservação do passado avançam no tratamento de seus fundos arquivísticos, ampliam-se as possibilidades de construção da historiografia da música com maior amplitude inclusiva de fatos, vultos e épocas. A obra musical transmitida graficamente é a forma de maior difusão no Brasil. 0 acesso a estes documentos apresenta novas possibilidades de percepção da memória, muito em especial das dinâmicas de elaboração, prática e recepção de um único exemplar, ou um conjunto, em regiões próximas e/ou distantes, assim como os processos de manutenção das mesmas através de diferentes gerações de músicos.

Fruto de uma constante prática, tanto de música sacra como secular, desde o inicio de sua história até os dias atuais, o patrimônio musical arquivístico mineiro 
está, em sua maior parte, fragmentado em expressiva quantidade de arquivos nas diferentes regiões geopolíticas do estado. As transformações sociais, políticas e econômicas observadas no decorrer da história comprometeram práticas diversas, dentre elas o uso da música sacra em cerimônias litúrgicas e paralitúrgicas com aparato instrumental e vocal à base de orquestra, coral e solistas, executando obras com o texto em latim. Em pleno século XXI a região do Campo das Vertentes parece ser a única a conservar aspectos de um passado comum a todos. Neste contexto São João del-Rei se tornou única a manter semanalmente seis missas com música realizada com o efetivo acima mencionado, além de dezenas de novenas, a Semana Santa e outras cerimônias pontuais.

Para a edificação da história fundamentada no manuscrito musical, torna-se imperativo o método e a engenhosidade na leitura crítica documental permitindo, desta forma, uma coleta de dados que sejam em quantidade suficiente, objetivos, claros e dentro de um sistema que garanta a lógica e a coerência. A importância desta fonte é corroborada por Bellotto (2006, p. 25). quando afirma que os arquivos permanentes "são a matéria-prima da história" Este artigo tem como objeto de investigação um conjunto de documentos musicais pertencentes ao arquivo da Orquestra Lira Sanjoanense, instituição musical que em 2016 completou 240 anos de existência e prática de música sacra de forma ininterrupta, os quais são submetidos a uma ferramenta metodológica da Diplomática, constituída esta de elementos pertinentes à análise de processos de difusão da obra musical grafada.

A estrutura do presente trabalho está organizada em quatro partes que necessitam ser explicadas. Em um primeiro momento, serão abordados aspectos históricos da instituição Orquestra Lira Sanjoanense, ressaltando-se questões sociais e culturais que corroboraram por mais de dois séculos para a criação e consolidação da referida Orquestra. Em seguida, ressaltar-se-á a respeito da origem, bem como dos métodos de utilização, da ferramenta Tradição Diplomática Documental. O terceiro tópico está destinado a demonstrar a aplicação da ferramenta Diplomática em alguns conjuntos de cópias de documentos musicais encontrados no arquivo da Orquestra Lira Sanjoanense. Por fim, realizar-se-á algumas considerações finais a respeito do presente trabalho, demonstrando e ressaltando a possibilidade de ampliação da aplicabilidade da ferramenta 
Diplomática no campo musicológico Sul-americano e, ainda, sua respectiva contribuição para o desenvolvimento dos estudos arquivístico e musicais.

\section{Orquestra Lira Sanjoanense}

Se no inicio do século XVIII estão os primeiros atos históricos de conquista e consolidação política do Estado de Minas Gerais é na segunda metade dos setecentos que observamos intensa atividade musical dentro e fora da igreja, consumindo obras de mestres da velha Europa, ao mesmo tempo praticando música original, fruto de expressivo número de compositores locais assim como de outras partes do Brasil. O surgimento da Orquestra Lira Sanjoanense está pontualmente inserido em um momento que o cenário musical nas Minas Gerais detinha nomes como o de José Joaquim Emerico Lobo de Mesquita, Manoel Dias de Oliveira, Marcos Coelho Neto, Inácio Parreira Neves, Francisco Gomes da Rocha e Jerônimo de Souza Lobo. Ainda que atividades musicais constem em registros desde 1717, obras autorais daqueles compositores estão situadas a partir da década de 1770, com progressivo aumento na medida de avanço do tempo.

Em São João del-Rei, cidade do Campo das Vertentes em Minas Gerais, o músico José Joaquim de Miranda firma contrato com a Irmandade de Nossa Senhora do Rosário em 1776, comprometendo-se a realizar a música nas festividades e celebrações durante o mesmo ano (COELHO, 2014, p. 133). Este ato de compromisso é considerado o momento de formação daquela que conhecemos hoje como Orquestra Lira Sanjoanense. Assim como os Souza Lobo em Vila Rica, atual Ouro Preto, José Joaquim e seus familiares constituíam o clã dos Miranda, grupo constante na realização das funções musicais e, desta forma, consolidando o sentido de equipe de trabalho, consequentemente um conjunto estável. 0 possível primeiro nome do conjunto foi Companhia da Música, constatado em diversas cópias ainda no inicio do século XIX, mudando posteriormente para Filarmônica Paulina, Lyra Sanjoanense até $o$ atual.

Uma vez estabelecido o grupo e suas funções é natural a constituição de um arquivo enquanto elemento estratégico na reposição e manutenção de obras musicais. Desta forma se inicia a acumulação de documentos musicais que hoje constituem o arquivo da Orquestra Lira Sanjoanense que, desde a fundação, jamais interrompeu sua agenda de atuação, contabilizando uma média de duas centenas de 
participação, ao longo de todo o ano, em diferentes igrejas assim como cerimônias de diversas irmandades, dentre elas Boa Morte, Rosário, Mercês, São Gonçalo Garcia, Nossa Senhora do Pilar, São Sebastião entre outras.

Em 240 anos de existência da "Lira”, diferentes gerações de músicos, regentes e compositores contribuíram com acréscimo de novas obras musicais procedentes do próprio Estado de Minas Gerais, assim como de outras partes do Brasil e de países da Europa, a exemplo de Portugal, Itália, França e Alemanha. Ainda não catalogado, mas em pleno processo de listagem e codificação das obras, constatamos a presença de cópias confeccionadas no século XVIII contendo música de João José das Chagas (1792), Lourenço José Fernandes Braziel (1798) e Joaquim de Paula Souza (1799) além de outras sem data fixada na fonte. Há grande quantidade de cópias da primeira metade do século XIX, nas quais consta música de José Joaquim Emerico Lobo de Mesquita, Manoel Dias de Oliveira, Marcos Coelho Neto e João de Deus Castro de Castro Lobo. Dentre os principais músicos da Orquestra Lira Sanjoanense a assinar as cópias estão Hermenegildo José de Souza Trindade, José Joaquim de Miranda e seu filho Francisco de Paula Miranda.

Compositores membros da própria Orquestra estão representados com expressivo conjunto de cópias autógrafas e de tradição. Dentre eles destacamos o Pe. José Maria Xavier, Francisco Martiniano de Paula Miranda, Luiz Batista Lopes, João Feliciano de Souza, Marcos dos Passos Pereira, José Joaquim de Souza Lira e Geraldo Barbosa de Souza. De compositores locais citamos os nomes de Antônio dos Santos Cunha, João Francisco da Matta, José Raimundo de Assis, Presciliano José da Silva, Firmino José da Silva, Martiniano Ribeiro Bastos além de outros. Da região registramos os nomes de Antônio de Pádua Falcão (Tiradentes), Fernand Jouteux (Tiradentes), Antônio Américo da Costa (Prados) e Antônio Martiniano da Silva Bemfica (Aiuruoca).

A representatividade geográfica dentro do arquivo da Orquestra Lira Sanjoanense não se restringe a Minas Gerais e nem ao Brasil. Cópias provenientes do Rio de Janeiro e São Paulo fazem parte do fundo arquivístico. Para exemplificar constam obras do Pe. José Maurício Nunes Garcia, Francisco Manoel da Silva, D. Pedro I, Gabriel Fernandes da Trindade, Henrique Alves de Mesquita, Francisco da Luz Pinto, Antônio Carlos Gomes e seu irmão José Pedro Santana Gomes. De 
nacionalidade portuguesa estão representados Marcos Portugal, Pedro Teixeira de Seixas, João José Baldi e Antônio Joaquim Nunes. Da mesma forma os italianos David Perez, Giuseppe Saveiro Raffaelle Mercadante e Fortunato Mazziotti entre outros.

\section{Tradição Diplomática Documental}

O surgimento da Diplomática teve início, principalmente, com os questionamentos sobre falsificações e dúvidas a respeito da autenticidade de documentos medievais. Em 1643, alguns jesuítas franceses, liderados por Jean Bolland, resolveram publicar uma imensa obra que tinha como objetivo contar a história dos santos, conhecida por Acta Santorum, a qual tinha como finalidade, de acordo com os jesuítas, buscar avaliar criteriosamente a vida dos santos, separando, dessa forma, a realidade das lendas.

Após a conclusão da obra, em 1645, Daniel Van Papenbroeck, tido como um dos jesuítas especialistas no trato documental, declarou em sua introdução que um diploma assinado pelo rei Dagoberto I seria falso. Como consequência desse fato, vários diplomas medievais, até então preservados e tratados como autênticos pelos beneditinos da Abadia de Saint Denis, seriam invalidados e sua autenticidade posta em dúvida. Com isso, o jesuíta realizava sua "crítica documental". Todavia, os beneditinos não se conformaram com as críticas que foram tecidas por parte dos jesuítas franceses, tal indignação pode ser justificada pelo fato de que eles "se julgavam especialistas nessas questões, já que, tradicionalmente, dedicavam-se aos trabalhos de busca e reprodução de documentos e que já tinham realizado inúmeros estudos de heurística e crítica de textos" (BELLOTTO, 2006, p. 15-16).

Como consequência da desconfiança por parte dos jesuítas em relação aos beneditinos, gerou-se certa indignação que desencadeou na chamada Guerra Diplomática. Ocorridas durante o século XVII, as guerras diplomáticas desenvolveram-se dentro das instituições religiosas e possibilitou o surgimento de um "grande número de disciplinas técnicas modernas que tendiam a determinar a confiabilidade dos documentos históricos, entre elas a Pal eografia, a Sigilografia e a Diplomática" (RODRGIUES, 2008, p. 121).

No ano de 1681, Jean de Mabillon, beneditino da Abadia de Saint Denis, decidiu responder àquela desconfiança feita pelos jesuítas por meio de uma obra 
dividida em seis partes, que ficou conhecida com De Re Diplomatica Libri Six, que tinha como objetivo principal estabelecer regras fundamentais para a crítica textual. A obra ganhou tanto respeito e credibilidade que muitos teóricos posteriormente passaram a considerá-la como sendo o marco inicial da ciência Diplomática. Os argumentos propostos por Gomes (1998) reforçam essa premissa, ao relatar que o surgimento da Diplomática ocorreu dentro das estruturas intelectuais da Igreja Católica do século XVII, "devendo-se a D. Jean Mabillon, beneditino da Congregação de Saint-Maur (França), a sua certidão de batismo lavrada com a publicação dos $D e$ Re Diplomatica Libri Sex (1681)”. Dessa forma, pode-se entender que a referida obra possibilitou um grande avanço aos estudos documentais daquele período, estabelecendo regras e princípios fundamentais, elaborando, assim, um marco inicial e literário para os estudos da ciência Diplomática (GOMES, 1998, p. 625).

A Diplomática, ao longo dos últimos séculos, foi submetida a diversas interpretações no que se refere a sua finalidade bem como ao seu objeto de estudo. Surgiram inúmeros teóricos e estudiosos que aos poucos foram contribuindo, por meio de seus posicionamentos teóricos, para o aprimoramento das técnicas de aplicação da ciência em estudo. O italiano Giorgio Cencetti considera que a Diplomática "é a disciplina que estuda a gênese, forma e transmissão de documentos arquivísticos" bem como "sua relação com os fatos representados nele e com seu autor com o fim de identificar, avaliar e comunicar sua verdadeira natureza" (CENCETTI, 1952, apud BERWANGER; LEAL, 2012, p. 25).

Entretanto, de acordo com os argumentos de Bellotto (2002), o estudo diplomático foca na identificação, avaliação e demonstração da natureza do conteúdo documental, considerando a relação com seu criador através de aspectos internos e o ato de sua transmissão. Com isso, na visão da autora, "hoje, este é o objetivo da Diplomática, muito mais do que simplesmente a autenticidade formal dos documentos", ampliando, assim, significativamente o conceito e finalidade dos estudos diplomáticos na atualidade (BELLOTTO, 2002, p. 17).

De forma ampla, pode-se ressaltar que o "documento" é o elemento central e essencial dos estudos diplomáticos desde o surgimento desta ciência. Contudo, se faz necessário demonstrar algumas conceituações a respeito da forma que o termo documento poderá vir a ser compreendido, ou seja, seu significado pode se 
apresentar sob tipos diversos de entendimento, no entanto, apesar dessas variações, existe um consenso, por parte dos autores, de que o termo possui aspectos de conceituações complexas. Enfatizando esses argumentos, Gomes (1998) apresenta de forma clara um posicionamento teórico ao ressaltar que "a Diplomática é uma ciência histórica cujo objetivo é, a partir de metodologias e questões específicas, proceder ao estudo científico do documento escrito na sua forma e conteúdo," sendo utilizado como elemento definidor de "sua autenticidade e valor probatório enquanto testemunho de dados e factos históricos" (GOMES, 1998, p. 625).

De acordo com Bellotto (2006, p. 35) o "documento é qualquer elemento gráfico, iconográfico, plástico ou fônico pelo qual o homem se expressa”, e, ainda, "tudo o que seja produzido, por motivos funcionais, jurídicos, científicos, técnicos, culturais ou artísticos, pela atividade humana". Buscando reforçar seus argumentos, a autora destaca que os "documentos escritos, legalmente válidos e revestidos de determinadas formalidades; sendo prova jurídica ou administrativa de um ato, são objeto da diplomática", dessa forma, surge o termo Documento Diplomático como decorrência de uma junção de conceitos interdisciplinares (BELLOTTO, 2006, p. 46).

A respeito do conceito de Documento Diplomático, Guimarães e Rabello (2007) ressaltam algumas considerações interessantes ao informar que:

[...] os denominados documentos diplomáticos são aqueles que, a rigor, podem ser considerados documentos arquivísticos stricto sensu, pois reúnem elementos estruturais [...] que lhes permitem, em um primeiro momento, 'saciar' os objetivos administrativos de seu órgão gerador na medida em que se revelam suficientemente fidedignos para transmitir e representar toda uma dinâmica funcionaladministrativa para, em um segundo momento, e uma vez cumprida sua finalidade administrativa, atuarem como fonte de pesquisa por haverem adquirido (ou agregado) valor histórico (GUIMARÃES \& RABELLO, 2007, pp. 139-140).

No entanto, de acordo com os argumentos propostos por Terrero (2000), o conceito de documento, sob a ótica da ciência Diplomática, adquire maior complexidade, demonstrando, assim, a importância e profundidade que o termo conquistou no âmbito dos estudos teóricos da Diplomática. 0 referido autor destaca que:

[...] de modo algum se limita [os estudos da Diplomática] aos documentos antigos, medievais e modernos, escritos sobre suportes tradicionais: pedra, metal, [...] papiro, pergaminho e papel, senão aos documentos de todas as épocas, fixados e transmitidos por diferentes sistemas [...] eletrônico, etc., sem importar demasiado com sua categoria, tipologia e solenidade e, muito menos, sua natureza, conteúdo e valor, que pode ser totalmente diverso e não necessariamente jurídico-diplomático ou administrativo (TERRERO, 2000, p. 144 apud NASCIMENTO 2009, p. 116). 
Mediante os diversos argumentos apresentados, a respeito do objeto de estudo que a ciência Diplomática se destina, pode-se compreender que o documento, entendido de forma ampla, possui lugar central nestas discussões, independentemente das divergências e variações teóricas a respeito do referido assunto. Entendendo o documento como sendo o objeto de estudo principal da Diplomática, se faz necessário a exposição teórica de uma de suas ferramentas de aplicação prática, a saber: a Tradição Diplomática Documental.

Submetendo-se a uma visão geral, entende-se a Tradição Diplomática Documental como sendo uma ferramenta de estudo da Diplomática que tem por objetivo compreender o processo de transmissão dos diversos tipos de informações por meio dos documentos. Cabe ressaltar que, basicamente, a Tradição Diplomática Documental destina-se ao estudo específico de duas formas de documentos, ou seja, os originais e/ou as cópias. Em concordância com essa assertiva, Berwanger e Leal (2012, p. 32) ressaltam que "tradição é a maneira de transmitir os documentos à posteridade, sendo formas de tradição os originais e as cópias". Possibilitando um entendimento mais amplo sobre a ferramenta diplomática em questão, Bellotto (2006) considera que a "tradição documental é a parte da diplomática que se ocupa dos vários modos de transmissão do documento no decorrer do tempo" e que "todas as formas de tradição documental se reduzem e se agrupam em torno de dois pólos quando, no âmbito dos arquivos permanentes, se tem o documento em mãos", ou seja, resumidamente, a referida autora considera dois tipos de estado em que os documentos podem ser encontrados, primeiramente, ou ele chegou à terceira idade na forma original e, a segunda forma, os documentos chegam em forma de cópias (BELLOTTO, 2006, p. 105).

No entanto, a referida autora atenta para o fato de que além desses dois "estados documentais" existem graduações na forma documental, inclusive na fase anterior à elaboração do documento original, denominada de minuta1. Pode-se verificar, ainda, a existência de três momentos distintos na aplicação da ferramenta Tradição Diplomática Documental, sendo eles: anterior ao original, o original e o posterior ao original. Outra importante informação que Bellotto (2006) destaca é a

\footnotetext{
${ }^{1}$ Bellotto explica que "minuta não é o rascunho e, sim, o pré-original. Por rascunho entende-se o texto sujeito a correções e rasuras e que contém supressões, acréscimos e substituições".
} 
de que existe a possibilidade de se verificar "categorias intermediárias" nesse processo de elaboração e transmissão documental. Sobre esse tipo de categoria documental, a autora destaca que "apesar de não serem originais, não chegam a ser cópias na real acepção da palavra" (BELLOTTO, 2006, p. 106). Portanto, diante desses argumentos, verifica-se que a ferramenta Tradição Diplomática Documental analisa o processo de transmissão das informações por meio de três categorias documentais, ou tipos documentais. A seguir, demonstrar-se-á, de forma clara e objetiva, algumas definições teóricas a respeito de cada categoria documental.

1. Documento original: é elaborado por vontade direta dos autores, sendo conservado na forma e matéria genuínas que foi inicialmente realizado.

2. Categorias intermediárias entre original e cópias: são as que se apresentam com características mais do que acessórias no sentido da Tradição Documental, entretanto, não chegam a ser consideradas como cópias. Enfim, tratam-se de ampliações, inserções ou renovações realizadas nos originais.

3. Cópia: tem como objetivo representar formalmente um documento idêntico ao original, no entanto, esse tipo de categoria documental pode possuir finalidades diferentes, como, por exemplo:

- Reproduzir originais existentes;

- Substituir originais desaparecidos.

Bellotto (2006, p. 106-108) e Berwanger e Leal (2012, p. 34) ressaltam que as cópias podem se apresentar em diversas modalidades, a saber:

1. Cópias simples ou livres: não possuem formalidade Diplomática, ou seja, não apresentam sinais de validação e nem formulário apropriado.

2. Cópias autênticas ou certificados: elaborados e autenticados com sinais públicos de autoridade de chancelaria ou pelos notários públicos, podendo ser posteriores ou contemporâneos ao original.

3. Cópias autógrafas: são feitas pela mesma pessoa (autor) que cria o documento autêntico. 
4. Cópias figuradas ou imitativas: são as que buscam reproduzir exatamente os caracteres do original.

5. Cópias de códices diplomáticos: podem apresentar-se em dois tipos opostos: os registros (cópias elaboradas pelo expedidor) e os cartulários (cópias feitas pelo destinatário).

Diante dessas definições pode-se perceber que as categorias documentais possuem diversos tipos de classificações, evidenciando, dessa forma, a especificidade que cada forma documental engloba. Portanto, entende-se que a compreensão da complexidade teórica, que a ferramenta Tradição Diplomática Documental abarca, se faz necessário antes mesmo de sua efetiva aplicação.

\section{Aplicação da ferramenta Tradição Diplomática Documental}

No intuito de demonstrar a aplicação da ferramenta Tradição Diplomática Documental foram selecionadas cinco obras de compositores diferentes. Cada obra apresenta uma quantidade variável de conjuntos de cópias. A justificativa da escolha das obras desses compositores baseia-se no fato de que cada um desses autores possui reconhecimento significativo na música do período colonial brasileiro, selecionando-se obras da segunda metade do século XVIII e da primeira metade do XIX, e, ainda, por evidenciar possíveis conexões musicais daquele período, uma vez que os documentos musicais em estudo se encontram no arquivo da Orquestra Lira SanJoanense, localizado na cidade de São João Del Rei, no estado de Minas Gerais. Outra informação relevante é a de que tanto os documentos autógrafos (originais) quanto os conjuntos de cópias são provenientes de lugares diversos, não se restringindo à cidade onde se encontra o atual arquivo musical.

Visando esclarecer os procedimentos que foram adotados na aplicação da ferramenta musicológica em questão, faz-se necessário destacar que as informações serão demonstradas em forma de tabela, dividida em quatro colunas, sendo que a primeira diz respeito a quantidade de conjuntos de cópias encontradas em cada obra, a segunda coluna informa a quantidade de partes que cada conjunto possui, na terceira encontrar-se-á o tipo de cópia daquele respectivo conjunto, podendo variar entre duas formas: simples ou autênticas. E, por último, na quarta coluna serão demonstrados os nomes dos respectivos copistas. Cabe, ainda, ressaltar que na 
primeira linha de cada tabela estão contidas as seguintes informações: nome da obra, bem como de seu respectivo compositor, e o código arquivístico da instituição.

\section{João de Deus de Castro Lobo}

Filho do músico Gabriel de Castro Lobo, João de Deus nasceu no ano de 1794, em Vila Rica, atual Ouro Preto. Ordenou-se padre na cidade de Mariana no ano de 1822 e em 1825 é nomeado Mestre da Capela da Catedral daquela localidade (CASTAGNA, 2012, p. 13). Compositor de música sacra, também é conhecido de sua lavra a Abertura em Ré, provável reflexo de experiência que teve, aos dezessete anos de idade, frente a uma orquestra de ópera atuando na Casa de Ópera de Vila Rica (FRIEIRO, apud CASTAGNA, 2012, p. 12). Não há notícias de qualquer autógrafo do compositor, mas é notória a expressiva difusão, através de copistas diversos, de suas composições em Minas Gerais e São Paulo. Seu falecimento se deu precocemente no ano de 1832 marcando, na visão de estudiosos, o final de uma época na história da música brasileira.

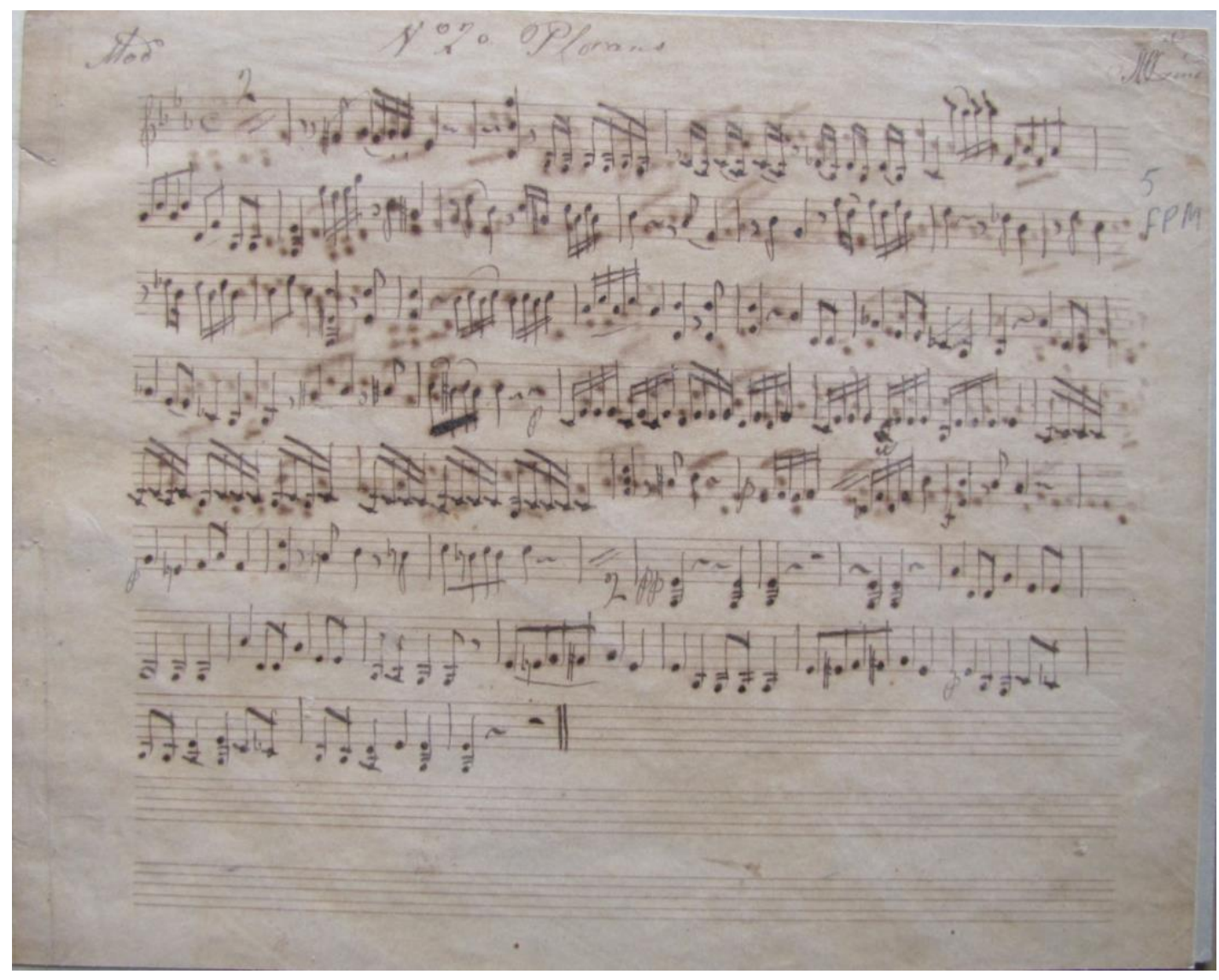

Figura 1: Exemplo de cópia autêntica. 


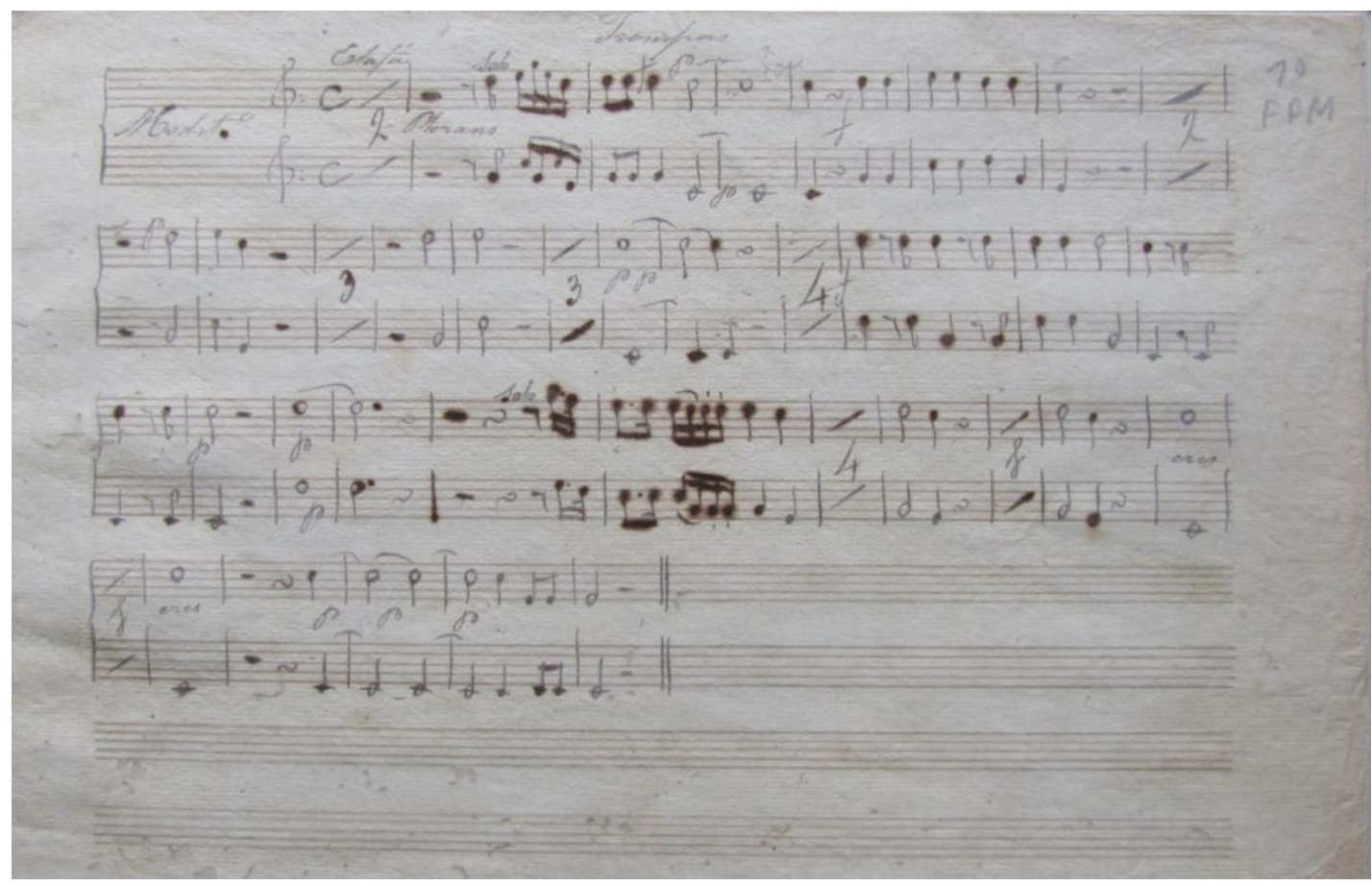

Figura 2: Cópia simples. Ausência da identificação por parte do copista.

Na sexta-feira que antecede o V Domingo da Quaresma é realizado em São João del-Rei o Setenário das Dores, cerimônia constituída de um conjunto de orações e pregações que refletem sobre o sofrimento de Maria na Paixão de Cristo (CATEDRAL, 1997, p. 69). Neste contexto são destacadas, como ponto central, as Sete Dores de Nossa Senhora. Dentre os textos há a Antífona Plorans ploravit, código OLS 0168 (Quadro 2), aqui selecionada como obra representante da produção de João de Deus de Castro Lobo e obra de grande difusão em Minas Gerais.

\begin{tabular}{|l|l|l|l|}
\hline \multicolumn{3}{|c|}{ PLORANS PLORAVIT - JOÃO DE DEUS CASTRO LOBO - OLS O168 } \\
\hline CONJUNTO & $\begin{array}{l}\text { QUANTIDADE DE } \\
\text { PARTES }\end{array}$ & $\begin{array}{l}\text { TIPO DE } \\
\text { CÓPIA }\end{array}$ & COPISTA \\
\hline 01 & 04 & AUTÊNTICA & $\begin{array}{l}\text { HERMENEGILDO JOSÉ DE SOUZA } \\
\text { TRINDADE }\end{array}$ \\
\hline 02 & 04 & SIMPLES & NÃO CONSTA \\
\hline 03 & 04 & AUTÊNTICA & $\begin{array}{l}\text { Pe. FRANCISCO DE PAULA } \\
\text { MACHADO }\end{array}$ \\
\hline 04 & 01 & SIMPLES & NÃO CONSTA \\
\hline 05 & 01 & SIMPLES & NÃO CONSTA \\
\hline 06 & 01 & AUTÊNTICA & J. DE SOUZA \\
\hline 07 & 01 & SIMPLES & NÃO CONSTA \\
\hline 08 & 10 & AUTÊNTICA & $\begin{array}{l}\text { ANTONIO CONEGUNDES DA } \\
\text { CRUZ }\end{array}$ \\
\hline 09 & 15 & AUTÊNTICA & MANOEL ROBERTO GOMES \\
\hline 10 & 14 & AUTÊNTICA & AGOSTINHO MATHEUS DE ASSIS \\
\hline
\end{tabular}

Quadro 2: Conjunto de cópias da obra Plorans Ploravit, do compositor João de Deus Castro Lobo. 


\section{Manoel Dias de Oliveira}

Sobre a vida de Manoel Dias de Oliveira destacam-se como principais pesquisas no Brasil aquelas realizadas por Toni (1985), Filho (1995) e Ricciardi (2000). 0 centro de atuação do músico foi na antiga São José del-Rei, hoje Tiradentes, município do Campo das Vertentes no estado de Minas Gerais. Em relação ao ano de seu nascimento há um documento de 1795 que afirma ter, neste mesmo ano, Manoel Dias de Oliveira a idade de 60 anos (FILHO, 1995, p. 55), portanto, pode ter nascido em 1735. É comum encontrarmos cópias de obras atribuídas ao compositor em expressivo número de arquivos musicais mineiros e de outros estados como São Paulo e Rio de Janeiro. Existem documentos registrando o pagamento ao músico para compor obras para diferentes irmandades (TONI, 1985, 57 e RICCIARDI, 2000, p. 158), no entanto, apenas uma obra manuscrita pelo autor, de 1788, foi encontrada até o momento (Figura 3). Trata-se de música para os Tractus, Paixão e Bradados de 4 a feira Santa, atualmente item integrante da Coleção Francisco Curt Lange, códice 062, do Museu da Inconfidência em Ouro Preto, Minas Gerais (DUPRAT, 1991, p. 50). Manoel Dias de Oliveira faleceu em 1813 com a idade de 78 anos e está sepultado na igreja dos Pardos de São João Evangelista em Tiradentes (FILHO, 1995, p. 58).

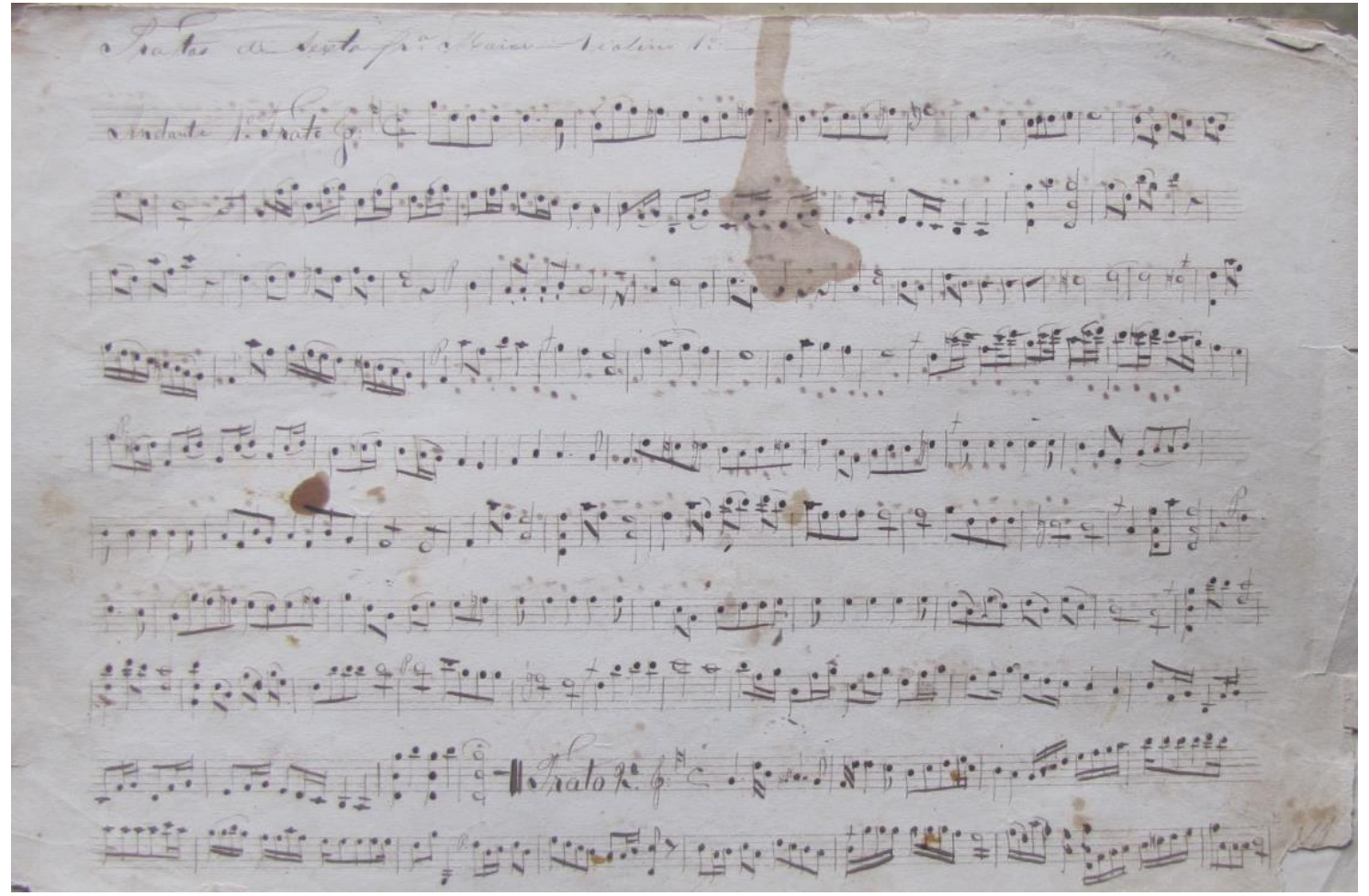

Figura 3: Cópia simples da obra Tractus e Bradados de Sexta-feira Santa, de Manoel Dias de Oliveira. 
A obra Tractus e Bradados, selecionada para esta pesquisa, pertence ao arquivo da Orquestra Lira Sanjoanense, com o código OLS 0317, e faz parte da liturgia da Sexta-Feira da Semana Santa. Nesta celebração, também conhecida como "Sexta-Feira da Paixão do Senhor", constam textos da primeira e segunda Lição do antigo Ofício Romano da Sexta-Feira Santa. Logo após há a Aclamação ao Evangelho seguida do Canto da Paixão (CATEDRAL, 1997, p. 329).

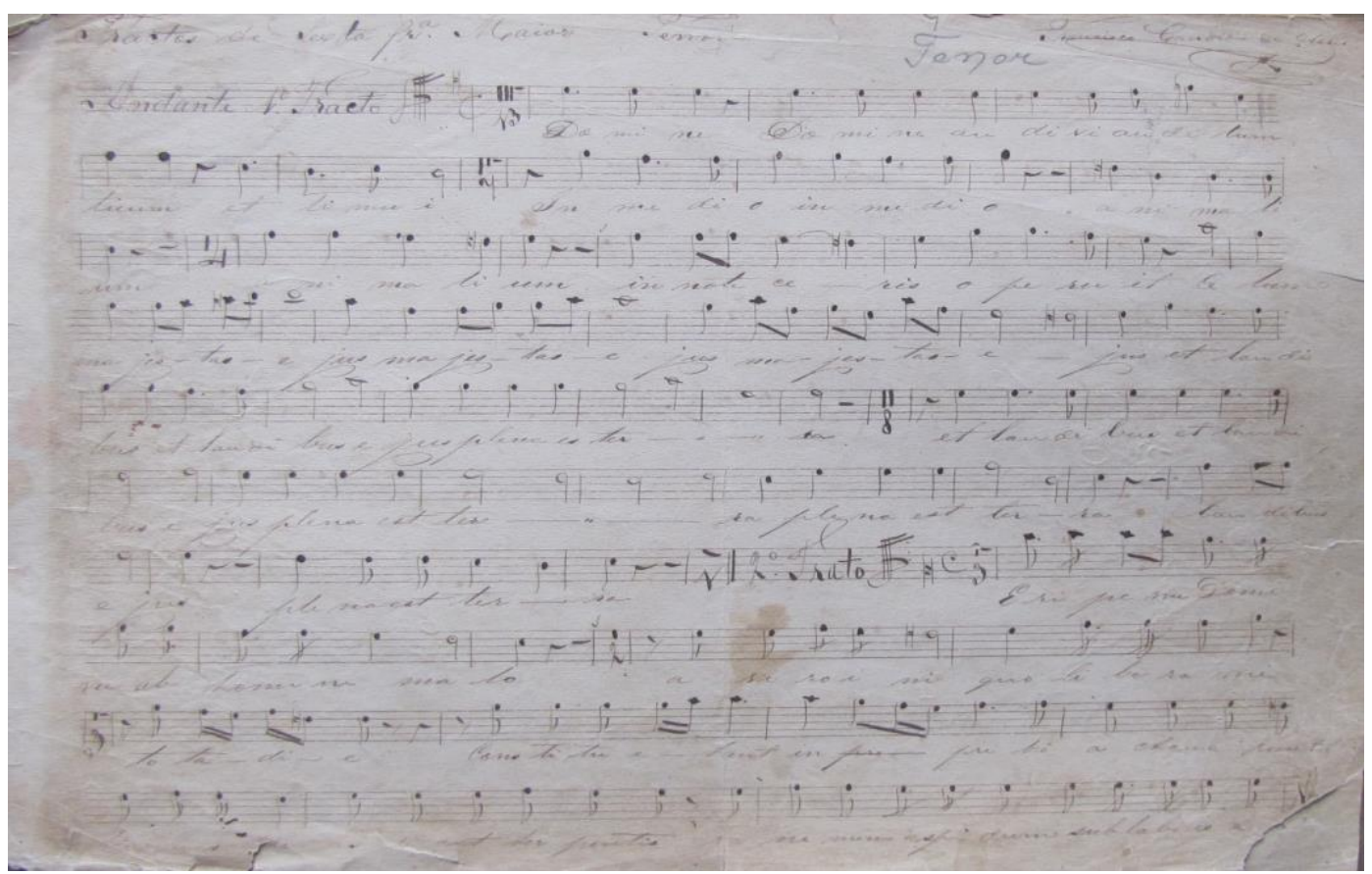

Figura 4: Exemplo de cópia autêntica. Tractus e Bradados de Manoel Dias de Oliveira.

\begin{tabular}{|l|l|l|l|}
\hline \multicolumn{2}{|c|}{ TRACTUS E BRADADOS DE SEXTA-FEIRA SANTA - MANOEL DIAS DE OLIVEIRA - } \\
OLS 0317 \\
\hline CONJ. & $\begin{array}{l}\text { QUANTIDADE DE } \\
\text { PARTES }\end{array}$ & TIPO DE CÓPIA & COPISTA \\
\hline 01 & 07 & AUTÊNTICA & $\begin{array}{l}\text { FRANCISCO CÂNDIDO } \\
\text { DE ASSIS }\end{array}$ \\
\hline 02 & 04 & SIMPLES & NÃO CONSTA \\
\hline 03 & 02 & SIMPLES & NÃO CONSTA \\
\hline 04 & 07 & AUTÊNTICA & $\begin{array}{l}\text { ANTÔNIO DE PÁDUA } \\
\text { FALCÃO }\end{array}$ \\
\hline 05 & 02 & SIMPLES & NÃO CONSTA \\
\hline 06 & 05 & SIMPLES & NÃO CONSTA \\
\hline 07 & 01 & SIMPLES & NÃO CONSTA \\
\hline 08 & 02 & SIMPLES & NÃO CONSTA \\
\hline
\end{tabular}

Quadro 3: Conjunto de cópias da obra Tractus e Bradados de Sexta-feira Santa, de Manoel Dias de Oliveira. 


\section{José Maurício Nunes Garcia}

Nasceu no Rio de Janeiro no ano de 1767, sede do vice-reinado da colônia portuguesa. Iniciou seus estudos musicais com Salvador José de Almeida e Faria, músico mineiro também conhecido como “o pardo" (MATTOS, 1996, p. 22). Compositor prolífero foi Mestre de Capela de D. João VI fazendo parte de um dos momentos de grande exuberância musical no Rio de Janeiro ao lado de Marcos Portugal e Sigismund Neukomm. A música de José Maurício teve grande difusão dentro e fora do Brasil, e em Minas Gerais é comum encontrar cópias em grande quantidade dos arquivos musicais conhecidos. Faleceu no ano de 1830 na capital fluminense e sempre foi nome que chamou a atenção de apreciadores da boa música, estudiosos e pesquisadores.

A cerimônia denominada Missa pode ser entendida como a representação da última ceia de Jesus Cristo junto aos Apóstolos (AMIOT, 1958, p. 11). Sua estrutura se fundamenta em duas partes, sendo a primeira denominada de ante-Missa constituída de orações iniciais, Coleta, leituras do Testamento, Antigo e Novo, cânticos intercalados, leitura do Evangelho, Homília e a oração do Credo. A Missa propriamente dita, segunda parte da estrutura, inicia com a liturgia do Ofertório. Para esta pesquisa selecionou-se documentos contendo a Missa em Mi bemol, com o código OLS 0245, obra de grande difusão em Minas Gerais, sendo localizada em diferentes arquivos musicais. 


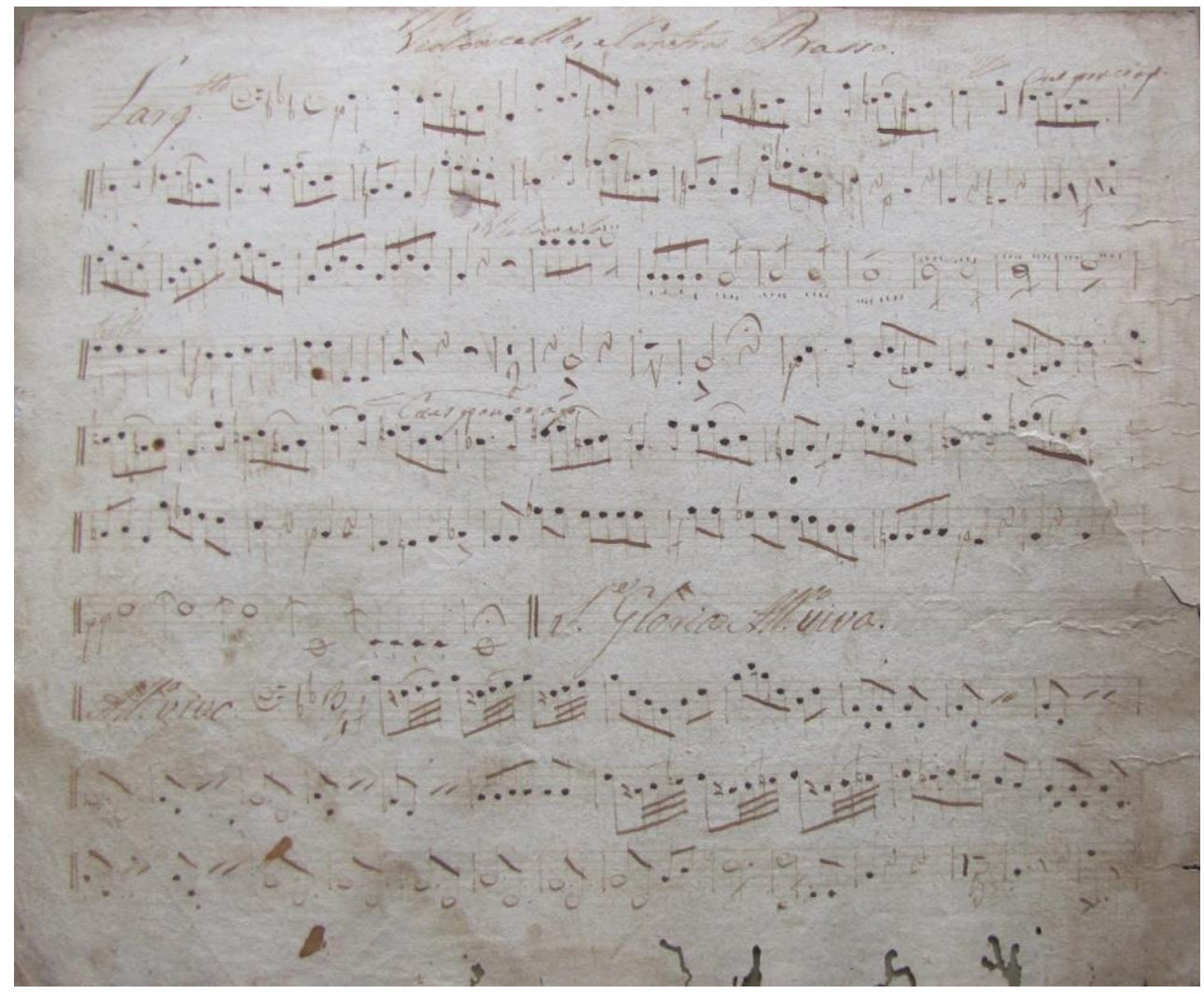

Figura 5 - Exemplo de cópia simples. Missa em Mi bemol de José Mauricio Nunes Garcia.

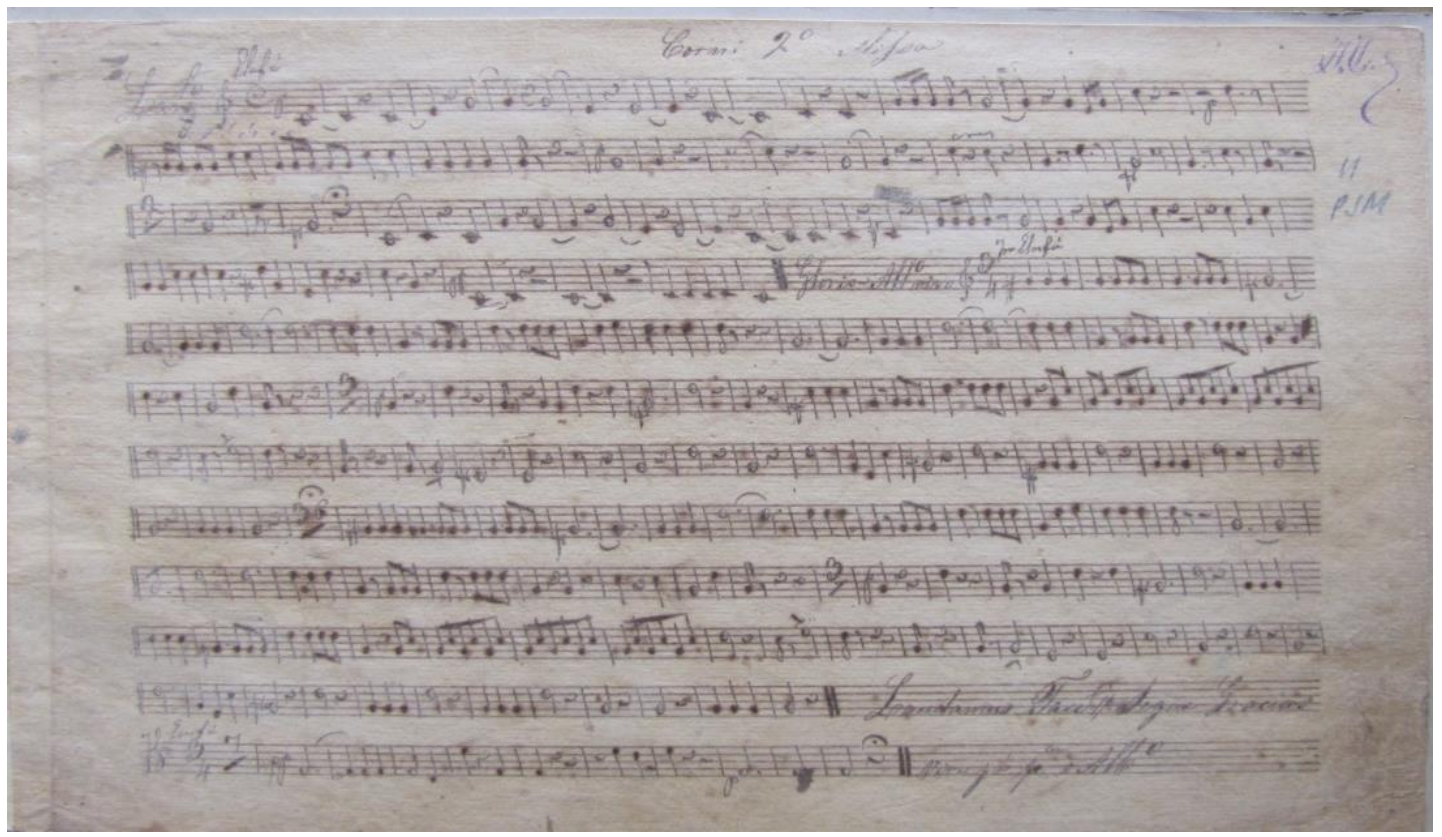

Figura 6: Cópia autêntica da Missa em Mi bemol, de José Maurício Nunes Garcia. 


\begin{tabular}{|l|l|l|l|}
\hline \multicolumn{3}{|c|}{ MISSA EM MI BEMOL - JOSÉ MAURÍCIO NUNES GARCIA - OLS O245 } \\
\hline CONJUNTO & $\begin{array}{l}\text { QUANTIDADE DE } \\
\text { PARTES }\end{array}$ & $\begin{array}{l}\text { TIPO DE } \\
\text { CÓPIA }\end{array}$ & COPISTA \\
\hline 01 & 08 & AUTÊNTICA & $\begin{array}{l}\text { ANTÔNIO ÂNGELO DA COSTA E } \\
\text { MELO }\end{array}$ \\
\hline 02 & 02 & AUTÊNTICA & MARTINIANO RIBEIRO BASTOS \\
\hline 03 & 02 & AUTÊNTICA & GUERRA BARRETO \\
\hline 04 & 13 & AUTÊNTICA & $\begin{array}{l}\text { HERMENEGILDO JOSÉ DE SOUZA } \\
\text { TRINDADE }\end{array}$ \\
\hline 05 & 04 & SIMPLES & NÃO CONSTA \\
\hline 06 & 01 & AUTÊNTICA & CRISTÓVAM GONÇALVES PINTO \\
\hline 07 & 03 & AUTÊNTICA & PARREIRA \\
\hline 08 & 02 & AUTÊNTICA & ALUÍZIO JOSÉ VIEGAS \\
\hline 09 & 02 & SIMPLES & NÃO CONSTA \\
\hline 10 & 09 & AUTÊNTICA & PEDRO DE SOUZA \\
\hline
\end{tabular}

Quadro 4: Conjunto de cópias da Missa em Mi bemol, de José Maurício Nunes Garcia.

\section{José Joaquim Emerico Lobo de Mesquita}

Considerado como um dos principais compositores das Américas no século XVIII, José Joaquim Emerico Lobo de Mesquita também foi organista. Existe a probabilidade de ter o compositor nascido na antiga Vila do Príncipe, atual Serro, entre os anos de 1740 e 1750. Transferiu-se para o Arraial do Tejuco, atual Diamantina, em fins de 1783, onde atuou como professor, organista e compositor. Em 1798 vai para Vila Rica, atual Ouro Preto, e em 1800 para o Rio de Janeiro onde, em dezembro de 1801, assina contrato com a Ordem Terceira do Carmo. Nesta última permanece no cargo de organista até seu falecimento em 1805 (GUIMARÃES, 2005, pp. 24-25). Dentre os compositores mineiros atuantes no século XVIII, é aquele que legou à atualidade a maior quantidade de manuscritos autógrafos e datados, sendo atribuídas à sua autoria cerca de 50 obras. 


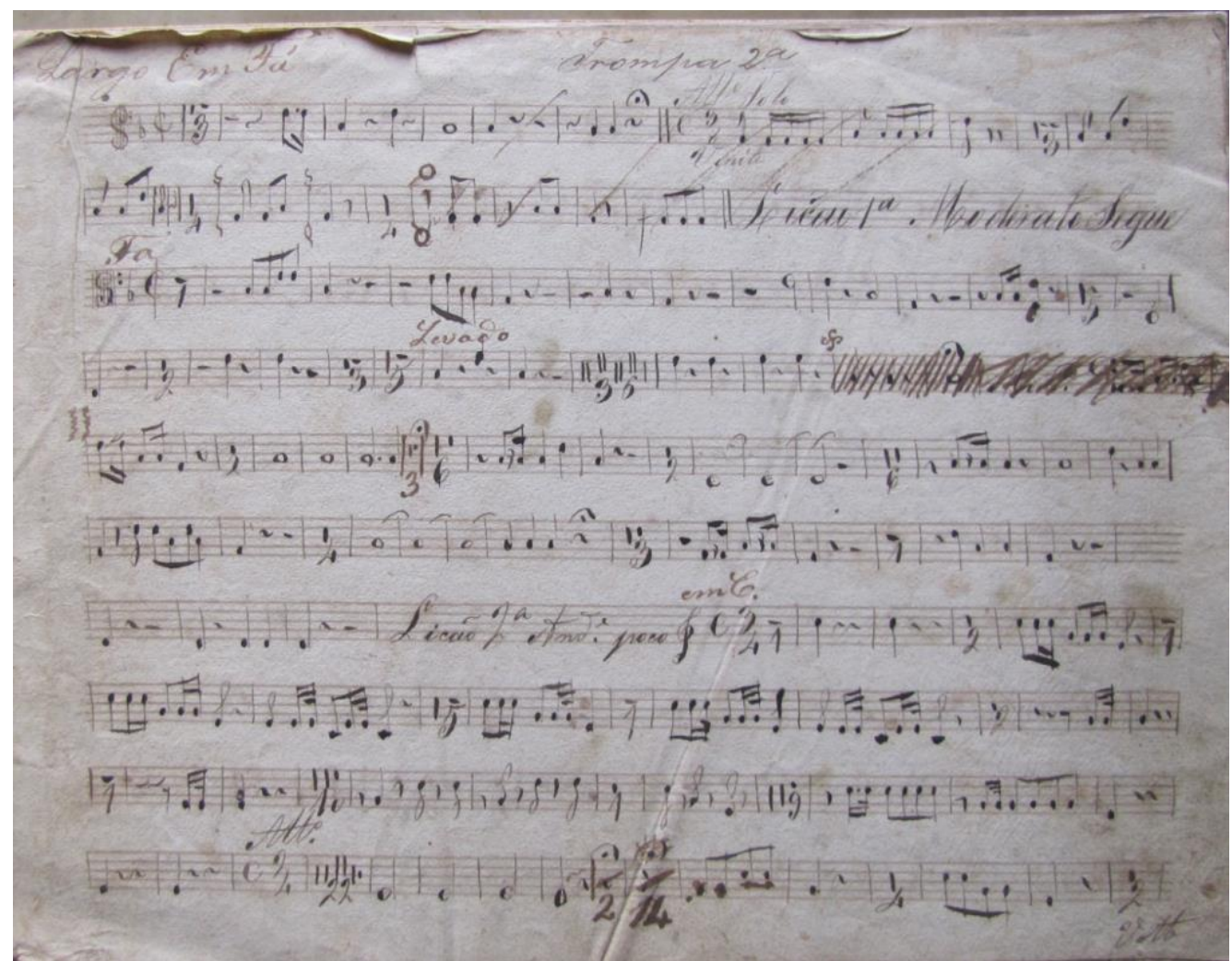

Figura 7: Cópia simples da obra Ofício de Violetas, de José Joaquim Emerico Lobo de Mesquita.

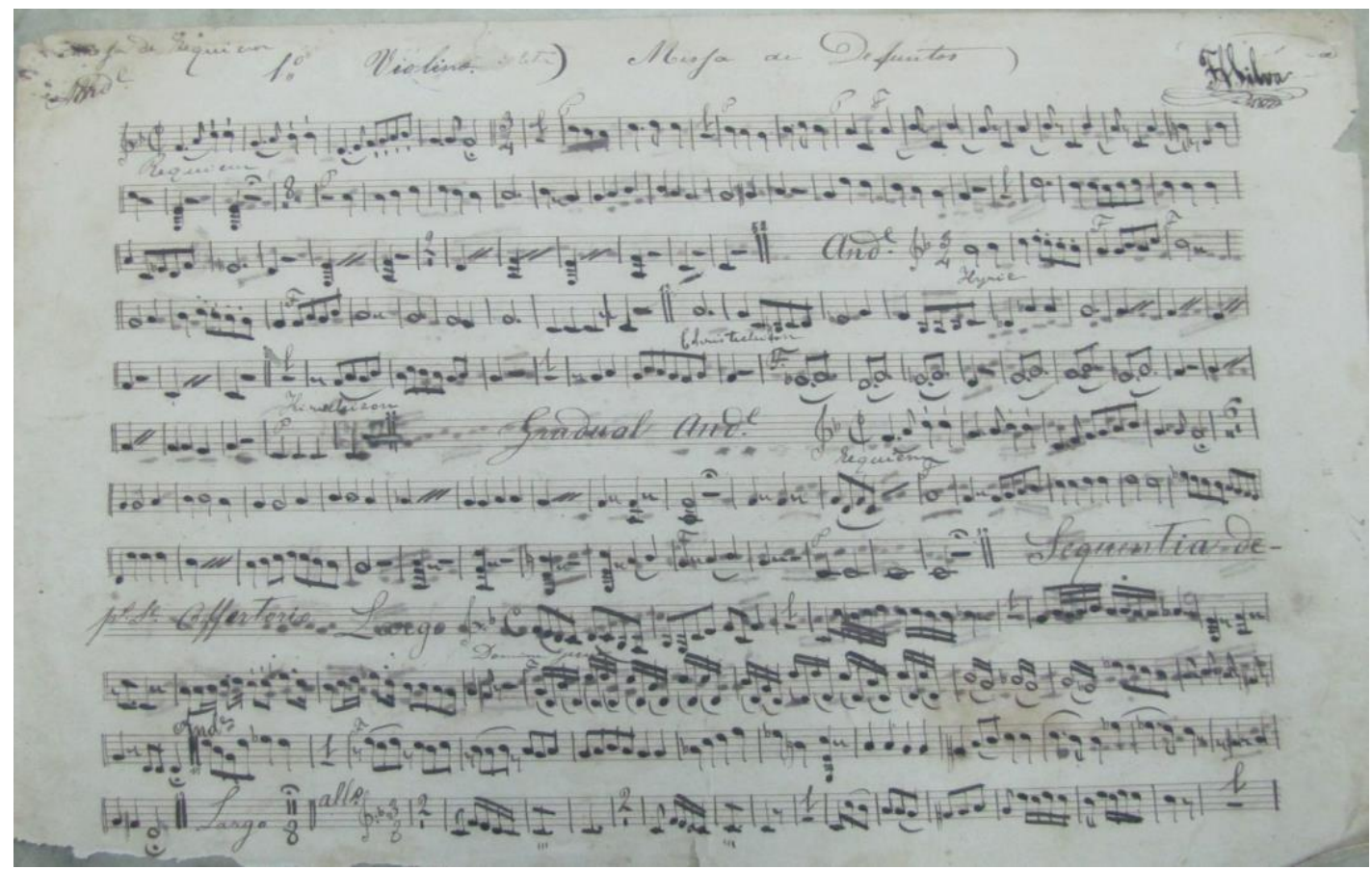

Figura 8: Exemplo de cópia autêntica. Oficio das violetas de José Joaquim Emerico Lobo de Mesquita. 
A obra conhecida como Ofício de Violetas, com o código OLS 047 no arquivo da Orquestra Lira Sanjoanense, é uma música com textos destinados a cerimônias fúnebres. A expressão "violetas” foi, provavelmente, acrescentada por algum copista no ato de produzir novas cópias que, considerando a presença de duas violas, à época também denominada como violetas, em lugar dos dois violinos, optou por registrar este pormenor no título da obra (Quadro 5).

\begin{tabular}{|l|l|l|l|}
\hline \multicolumn{2}{|c|}{ OFÍCIO DE VIOLETAS - JOSÉ JOAQUIM EMERICO LOBO DE MESQUITA - OLS O471 } \\
\hline CONJUNTO & $\begin{array}{l}\text { QUANTIDADE DE } \\
\text { PARTES }\end{array}$ & $\begin{array}{l}\text { TIPO DE } \\
\text { CÓPIA }\end{array}$ & COPISTA \\
\hline 01 & 01 & AUTÊNTICA & $\begin{array}{l}\text { HERMENEGILDO JOSÉ DE SOUZA } \\
\text { TRINDADE }\end{array}$ \\
\hline 02 & 01 & SIMPLES & NÃO CONSTA \\
\hline 03 & 02 & SIMPLES & NÃO CONSTA \\
\hline 04 & 02 & SIMPLES & NÃO CONSTA \\
\hline 05 & 09 & SIMPLES & NÃO CONSTA \\
\hline 06 & 03 & AUTÊNTICA & MARTINIANO RIBEIRO BASTOS \\
\hline 07 & 08 & AUTÊNTICA & FRANCISCO JOSÉ DAS CHAGAS \\
\hline 08 & 17 & AUTÊNTICA & PEDRO DE SOUZA \\
\hline 09 & 01 & SIMPLES & NÃO CONSTA \\
\hline 10 & 01 & SIMPLES & NÃ̃O CONSTA \\
\hline 11 & 13 & SIMPLES & NÃO CONSTA \\
\hline 12 & 01 & SIMPLES & NÃO CONSTA \\
\hline 13 & 01 & SIMPLES & NÃO CONSTA \\
\hline 14 & 01 & SIMPLES & NÃO CONSTA \\
\hline 15 & 10 & AUTÊNTICA & F. A. SILVA \\
\hline 16 & 02 & SIMPLES & NÃO CONSTA \\
\hline 17 & 09 & SIMPLES & NÃOO CONSTA \\
\hline 18 & 04 & SIMPLES & NÃ̃O CONSTA \\
\hline
\end{tabular}

Quadro 5: Cópias da obra Ofício das Violetas, de José Joaquim Emerico Lobo de Mesquita.

\section{Jerônimo de Souza Lobo}

Membro do clã dos Souza Lobo, com registro de atuação musical em Vila Rica, atual Ouro Preto, desde a segunda década do século XVIII (CARDOSO, 2008, p. 27), seu nome é recorrente em arquivos de manuscritos musicais em Minas e São Paulo, sendo atribuída a ele significativa listagem de obras. A escassez de documentação contendo informações sobre o músico não permite afirmações pormenorizadas a seu respeito, colocando-o em meio a dúvidas de identidade entre, pelo menos, dois outros compositores com nomes semelhantes e membros da família Souza Lobo (Souza Lobo Lisboa e Souza Lobo Queiroz). Na difusão das obras deste grupo de compositores os copistas, já no século XIX, omitiam o nome do compositor, e quando 
o faziam registravam apenas Jerônimo de Souza. ${ }^{2}$ Dentre as obras conhecidas há música para as Matinas, ou Ofícios, da Semana Santa (Figura 9), Matinas de Santo Antônio, São Francisco e Ladainhas diversas, ainda não sendo unanimidade as respectivas atribuições de autoria.

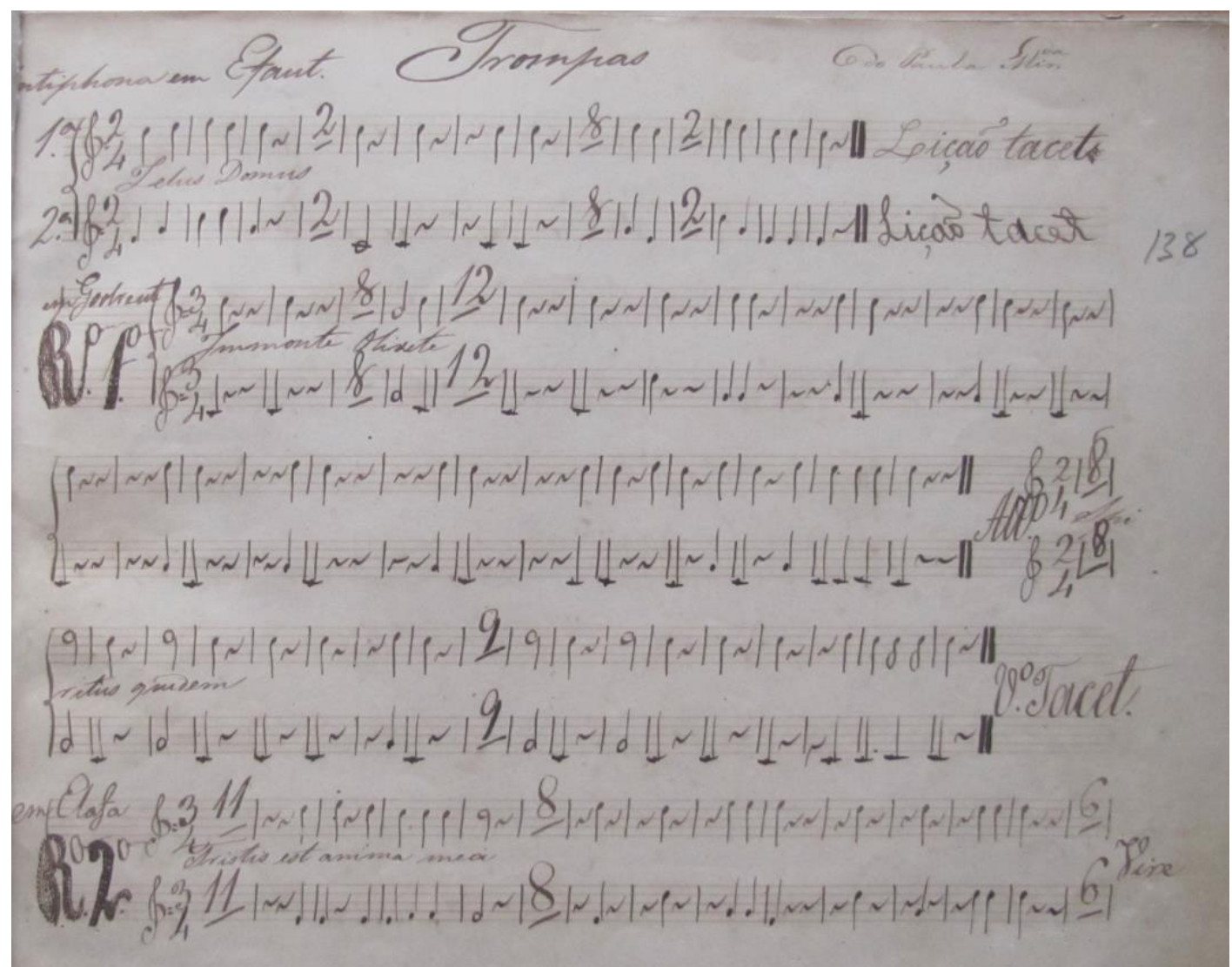

Figura 9: Cópia autêntica da obra Ofício de Sexta-feira Santa, de Jerônimo de Souza Lobo.

${ }^{2}$ Idem, p. 28. 


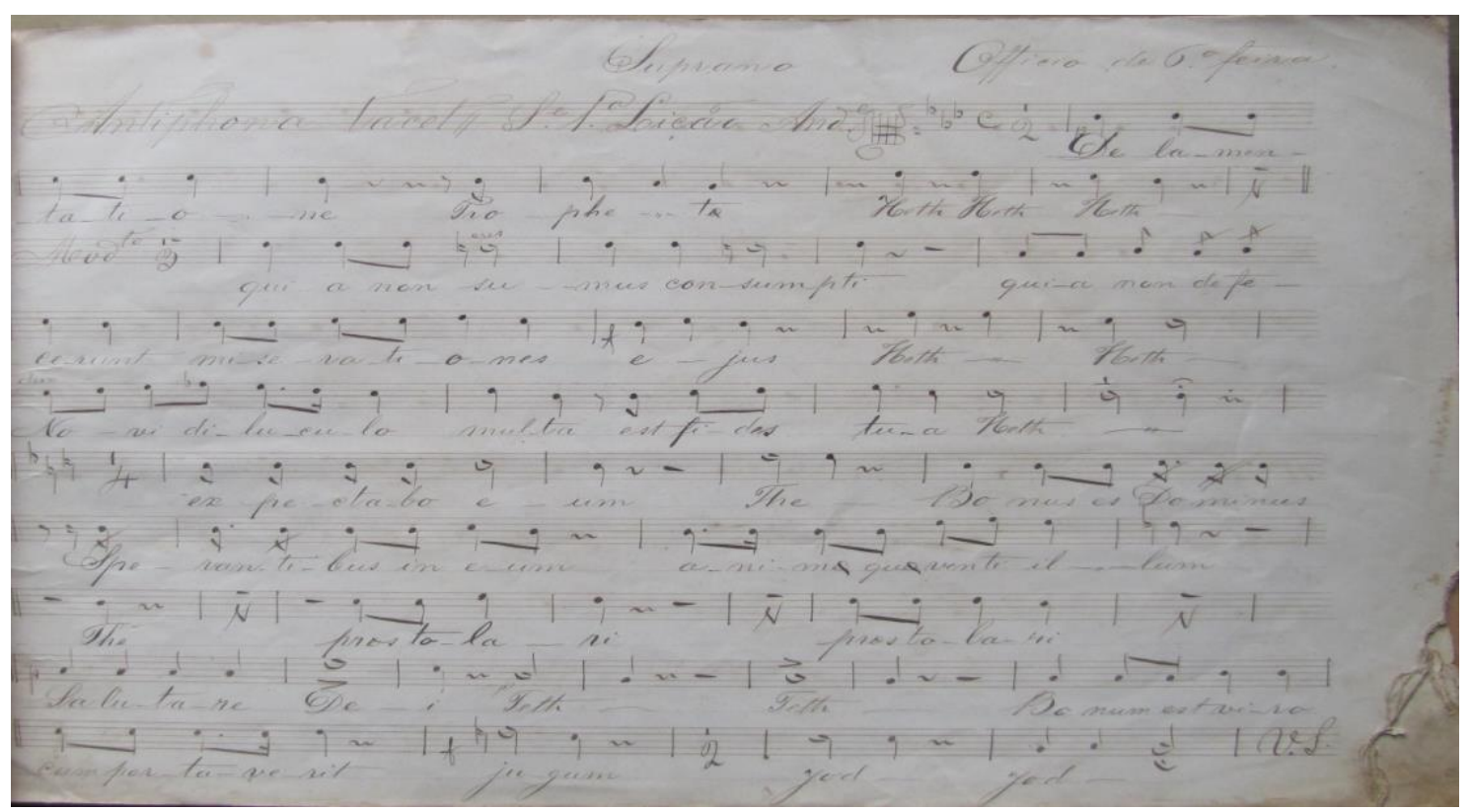

Figura 10: Cópia simples da obra de Jerônimo de Souza Lobo.

Matinas e Laudes são as partes do Ofício Divino utilizadas para realizar o Ofício de Trevas, celebrado Quinta-feira, Sexta-feira e Sábado da Semana Santa. A obra selecionada como exemplo da produção de Jerônimo de Souza foi o Ofício, ou Matinas, de Sexta-feira Santa, com o código OLS 0161 no arquivo da Orquestra Lira Sanjoanense (Quadro 6). Durante diversas leituras, orações e responsórios, são apagadas 14, de 15 velas, posicionadas em um grande candelabro triangular, e esta última, mantida acesa, representa Jesus Cristo, Luz que ilumina todo homem. Ao final da cerimônia todas as luzes da igreja são apagadas e ouve-se o ruído significando que o Senhor ressuscitou (CATEDRAL, 1997, p. 132).

\begin{tabular}{|l|l|l|l|}
\hline \multicolumn{4}{|l|}{ OFICIO DE SEXTA-FEIRA SANTA - JERÔNIMO DE SOUZA LOBO - OLS 0161 } \\
\hline CONJUNTO & QUANTIDADE DE PARTES & TIPO DE CÓPIA & COPISTA \\
\hline 01 & 09 & AUTÊNTICA & PAULA MIRANDA \\
\hline 02 & 11 & SIMPLES & NÃO CONSTA \\
\hline 03 & 01 & AUTÊNTICA & A. R. SILVA \\
\hline 04 & 01 & SIMPLES & NÃO CONSTA \\
\hline 05 & 01 & SIMPLES & NÃO CONSTA \\
\hline 06 & 01 & SIMPLES & NÃO CONSTA \\
\hline
\end{tabular}

Quadro 6: Cópias da obra Ofício de Sexta-feira Santa, de Jerônimo de Souza Lobo.

\section{Considerações Finais}

A historiografia da Orquestra Lira Sanjoanense ainda está por ser construída em sua plenitude ou, pelo menos, com a mais ampla abrangência possível. Fatos de incontestável relevância, assim como os nomes a eles associados, estão registrados 
publicamente, mas também é possível perceber que os mesmos vão se tornando recorrentes de um texto a outro, claro indicativo de estagnação na tarefa de localizar novas fontes primárias que possam conter aspectos inéditos na trajetória histórica da Orquestra.

Focar os fundos de seu arquivo de documentos musicais significa adentrar em alguns de seus aspectos mais exuberantes e instigantes: a prática musical pela ótica do repertório, a variedade de gêneros, as obras que permaneceram por longos períodos, aquelas outras que, aparentemente, sequer foram executadas, os copistas e suas preferências, somente para exemplificar. Mas, dentre todos, há alguns aspectos que vêm ganhando, cada vez mais, relevância em tarefas musicológicas, a saber, a edição musical, em especial a Crítica, e a descrição documental para confecção de instrumentos de busca tais como o inventário, lista e catálogo, que é o fenômeno da difusão da obra musical escrita, ou seja, sua transmissão de geração a geração.

A ferramenta Tradição Diplomática Documental, previamente demonstrada neste artigo, está se revelando como recurso munido de qualidades claramente próprias para a análise crítica do documento de interesse da musicologia. Esta ferramenta permite uma sistematização em todas as etapas do processo analítico, propiciando uma leitura organizada de forma a extrair dados em uma sequência lógica e criteriosa. A categorização documental proposta pela ferramenta estabelece, logo de início, um grau de distinção entre os documentos que constituem determinada amostragem.

Os dados atuais sobre arquivos de documentação musical em Minas Gerais já nos permite perceber e identificar localidades com maior atividade de criação de novas obras musicais em sua trajetória histórica, e aquelas que exerceram a replicação do produto das primeiras, sua assimilação e, em muitos casos, reelaboração em diferentes graus visando sempre a melhor adequação à sua conveniência. Assim é o caso, a título de exemplo, da substituição de instrumentos musicais do documento original para outros disponíveis no local de recepção da obra. Se a cópia documental é a categoria mais representativa em arquivos mineiros, o uso da ferramenta Tradição Diplomática Documental terá como alvo principal sua diversidade. 


\section{Referências bibliográficas}

AMIOT, François. A Missa e sua história. São Paulo: Livraria Editora Flamboyant, 1958.

BELLOTTO, Heloísa L. Arquivos permanentes: tratamento documental. 4⿳亠丷a ed. Rio de Janeiro: Editora FGV, 2006.

BERWANGER, Ana Regina \& LEAL, João Eurípedes Franklin. Noções de Paleografia e de Diplomática. 4⿳亠丷a ed. Santa Maria: Ed. da UFSM, 2012.

CARDOSO, André. Jerônimo de Souza. In: Patrimônio Arquivístico Musical Mineiro - Jerônimo de Souza: vol. 2. Coordenação Paulo Castagna - Belo Horizonte: Secretaria de Estado de Cultura, 2008.

CASTAGNA, Paulo. Produção musical e atuação profissional de João de Deus de Castro Lobo (1794-1832): do desaparecimento de seus autógrafos à transmissão de sua música pelas redes sociais. In: Opus - Revista eletrônica da ANPPOM. Vol. 18, n. 1, pp. 9-40, jun. 2012.

CATEDRAL do Pilar. Piedosas e Solenes Tradições de Nossa Terra: A Quaresma e a Semana Santa em São João Del Rei. Trabalho realizado pela equipe de Liturgia da Paróquia da Catedral Basílica de Nossa Senhora do Pilar. São João Del Rei, 2a. Ed., 1997.

CATROGA, Fernando. Memória, história e historiografia. Rio de Janeiro: Editora FGV, 2015.

COELHO, Eduardo L. Coalhadas e Rapaduras: estratégias de inserção social de músicos negros em São João Del-Rei (século XIX). Resende Costa, MG: AMIRCO, 2014.

CROCKER, Richard L. A history of musical style. New York: Dover Publications, 1986.

DUPRAT, Régis \& BALTAZAR, Carlos Alberto (Org.). Acervo de manuscritos musicais: Coleção Francisco Curt Lange. Volume I - Compositores mineiros dos séculos XVIII e XIX. Belo Horizonte: UFMG / Museu da Inconfidência, Ouro Preto, 1991.

FILHO, Olinto Rodrigues dos Santos. Capitão Manoel Dias de Oliveira, parca documentação para uma longa vida. In: I Encontro de Musicologia Histórica (Anais). Juiz de Fora, MG, pp. 54-61, 1995.

GUIMARÃES, Maria Inês Junqueira. "José Joaquim Emerico Lobo de Mesquita (1746?1805)”. In: COTTA, André Guerra (Org.). Lobo de Mesquita no Museu da Música de Mariana: homenagem a José Joaquim Emerico Lobo de Mesquita (1746?-1805) no bicentenário de seu falecimento, pp. 21-25. Mariana: FUNDAQ, 2005.

MATTOS, Cleofe Person de. José Maurício Nunes Garcia: biografia. Rio de Janeiro: Fundação Biblioteca Nacional, Departamento Nacional do Livro, 1996.

PIEDOSAS. Piedosas e Solenes Tradições de Nossa Terra: A Quaresma e a Semana Santa em São João Del Rei. II volume. Trabalho realizado pela equipe de Liturgia da Paróquia da Catedral Basílica de Nossa Senhora do Pilar. São João del-Rei, 2a. Ed., 1997.

RICCIARDI, Rubens R. Manoel Dias de Oliveira: Um compositor brasileiro em tempos coloniais-documentos e partituras. Tese (Doutorado em Artes), Pós-Graduação em Música, Escola de Comunicações e Artes, ECA, Universidade de São Paulo, USP, São Paulo, 2000.

TONI, Flávia C. A música nas irmandades da Vila de São José e o Capitão Manuel Dias de Oliveira. Dissertação de Mestrado. São Paulo, ECA-USP, 1985. 